\title{
Determinants of the Intention to Adopt Mobile Augmented Reality Apps in Shopping Malls among University Students
}

\author{
Vaggelis Saprikis ${ }^{1, *(1)}$, Giorgos Avlogiaris ${ }^{2}$ and Androniki Katarachia ${ }^{3}$ \\ 1 Department of Management Science and Technology, School of Economic Sciences, \\ University of Western Macedonia, 50100 Kozani, Greece \\ 2 Department of Statistics and Insurance Science, School of Economic Sciences, \\ University of Western Macedonia, 51100 Grevena, Greece; aff00084@uowm.gr \\ 3 Department of Accounting and Finance, School of Economic Sciences, University of Western Macedonia, \\ 50100 Kozani, Greece; akatarachia@uowm.gr \\ * Correspondence: esaprikis@uowm.gr
}

Received: 19 October 2020; Accepted: 17 November 2020; Published: 20 November 2020

check for updates

\begin{abstract}
Augmented Reality (AR) technology adoption has been growing worldwide in recent years. The potential of AR to blend digital information into the physical world has been a challenge for both academia and industry, who attempt to realize and anticipate its impact on users' perceptions, adoption intention and use. The present paper is an empirical study aimed at making substantial suggestions and investigating an integrative theoretical paradigm which attempts to establish the significance of specific factors which allow using mobile augmented reality apps in shopping malls. The study employs information from the extant literature with a view to extending the Unified Theory on Acceptance and Use of Technology (UTAUT). The results show that performance expectancy, enjoyment and reward are direct determining factors of adopting the specific technology in shopping malls, whereas facilitating conditions, social influence, innovativeness and trust exert an indirect effect on behavioral intention adoption. The research findings have far-reaching theoretical and practical implications for the development, marketing and application of mobile AR apps in the context of the specific contemporary form of shopping.
\end{abstract}

Keywords: augmented reality; adoption; UTAUT; mobile commerce; shopping mall

\section{Introduction}

\subsection{Augmented Reality Evolution}

Despite the fact that AR has been examined for more than 30 years, only quite recently, via smartphones, which offer powerful platforms to support $\mathrm{AR}$, have such technologies acquired great popularity and become affordable for a large number of mobile users [1-3]. Contemporary smartphones are equipped with special features to meet the requirements of a variety of AR applications, such as fast processors with graphics hardware, reasonably large touch screens, a relatively fast Internet connection, and built-in sensors (camera, GPS, Wi-Fi, compass, and accelerometer), which enable indoor and outdoor use of AR applications [4,5]. It is worth noting that the mobile gaming app 'Pokemon Go', based on AR technology, had an impressive appeal to a large number of users [6], and achieved more than one billion downloads worldwide in less than three years [7]; thus, it broadly gave a clear picture of the great variety of AR technology potential. Up to now, various AR applications, which have been developed in many industries, especially in tourism, education, construction, culture, gaming, retail and marketing [8-15], have revealed the significant and powerful capabilities of IT to create groundbreaking user experiences [9] 
and provide unique and exciting human-computer interaction [16]. AR's prospects are clearly depicted on Forbes Agency Council [17] estimations, according to which AR applications are expected to demonstrate significant annual growth at a rate of $75.72 \%$ and reach $\$ 117.4$ billion by 2022 .

The experience of utilizing AR provides users with numerous values and benefits $[18,19]$. It "can empower individuals with innovative context sensitive and proactive functionalities, raise awareness of information related to the surroundings with a very intuitive interface, make activities more efficient and offer personally and contextually relevant information that is reliable and up-to-date" ([3], p. 77). In addition, AR can speed up the decision-making purchase process, is easy to use, has entertainment value [20], and can be utilized to access personalized and relevant information at any time and place [21]. Karpischek and Michahelles [22] also claimed that this is a practical method, which can create connections between social content and physical products, thus challenging consumers to communicate and obtain information about products.

With regard to its business-oriented study, AR technology has already received the attention of academia, and has been investigated with a view to gaining valuable insight into AR's utilization. A number of relevant studies have focused on its applications and limitations (e.g., [16,23,24]), utilization (e.g., [3]) and usage intention (e.g., [8,11,25]), whereas a considerable number of researchers emphasized adoption intention [12,25-29].

In this context, the present empirical study was carried out in order to reveal key influential determinants, which have an impact on mobile users' behavioral intention to adopt an AR app in shopping malls. It is based on Venkatesh et al. [30] Unified Theory of Acceptance and Use of Technology (UTAUT). However, the paper proposes an integrated and holistic conceptual framework that extends Venkatesh et al. [30] technology adoption theory. Overall, shopping malls combine various sets of consumers' needs and daily tasks employed via AR, such as navigation, e-shopping, advertisements and marketing, mobile payment, additional product information, social interaction, etc. [15]. From this perspective, AR technologies can be conducive to fully transforming how traditional retail and marketing activities are carried out [31]. To illustrate, AR users can scan a product to read customers' reviews about it or compare its price with other stores, which offer the same product [14]. Additionally, AR technology enables the display of additional information about products and, thus, enhances the shopping experience or allows customers to find special prices or offers, and also encourage them to enter a store. Remarkably, AR is considered an effective marketing tool as it enables a new form of visualization and interaction [24]. More specifically, AR can enhance brand identity and advertising campaigns as it focuses on the entire customer experience rather than a product/service [32]. As a result, AR is perceived as a form of persuasive rather than functional technology, producing experiential value [19,33]. It is also seen as an innovation, which can create value in terms of enjoyment, efficiency, visual satisfaction and playfulness [18]. The results are expected to support the companies involved to plan a targeted business strategy aimed at increasing AR adoption and further use. In this context, the scope of the present research study is to identify the individuals' attitudes towards the different factors likely to affect their behavioral intention to adopt mobile AR apps for shopping, information and entertainment purposes. In detail, the study aims to develop an integrated framework, which will enable the explanations to be provided about the antecedents of using mobile AR applications in shopping malls. In addition, it contributes to the development and evolution of a theoretical and conceptual model to depict how different factors influence mobile users to adopt such AR apps. The hypotheses applied are based on the growing literature of the Information Technology and expected to explain the behavioral adoption intention phenomenon. The significance of the present empirical study is based on the fact that the use of mobile AR apps in shopping malls has been poorly investigated so far. In addition, no previous study has managed to model the factors affecting individuals' behavioral intention to adopt such AR apps in shopping malls in a solid framework, as well as examine the direct and indirect relationships between these variables at the same time. Thus, it offers valuable insight into the academic and industry stakeholders so that they would be able to build policies and follow specific strategies on mobile AR app development and marketing. 


\subsection{Behavioral Intention Theoretical Background}

An extensive literature review on Information Technology highlights various theories and conceptual models regularly applied or extended with potential factors to explore several perspectives of technology adoption. In this context, there are several popular behavioral intention schemes, such as the Theory of Reasoned Action (TRA) [34], the Theory of Planned Behavior (TPB) [35] and the Diffusion of Innovations (DOI) theory [36]. Technology Acceptance Model (TAM) is the leading theory in technology adoption [37,38]. The literature review points out that TAM has evolved to become a key model in understanding predictors of human behavior towards potential adoption or rejection of the technology [39]. The Unified Theory of Acceptance and Use of Technology (UTAUT) is the latest derivative of TAM [30]. Since being introduced, UTAUT has been expansively used in various fields, thus, promises to be a great tool for analyzing users' acceptance of AR technology. Actually, both of them have been the basic technology adoption models utilized in the relatively minimally investigated AR context (e.g., [28,40-42]).

More specifically, TAM emphasizes that perceived usefulness and perceived ease of use are the two key principles which control an individual's behavioral intention to use technology [43]. When researchers desire a deeper investigation of an individual's adoption intention, TAM enables other variables to be further used within the basic model [44]. Leue et al. [40] argued that TAM should be revised in an AR approach, and request for the addition of other constructs, such as cost of use or personal innovativeness. Rese et al. [25] confirmed that perceived ease of use, perceived usefulness and enjoyment have a positive impact on behavioral intention to adopt the IKEA's AR mobile catalogue app. In addition, Haugstvedt and Krogstie [2] stated that perceived usefulness and enjoyment have a direct impact on mobile AR adoption for cultural heritage, whereas and Pribeanu [45] claimed that enjoyment and perceived usefulness have a statistically more significant impact on the behavioral intention to use an AR teaching platform. Finally, Rauschnabel and Ro [28] highlighted the significance of perceived ease of use, functional benefits, individual difference variables, brand attitudes and social norms in AR smart glass behavioral adoption.

With regard to the UTAUT, it incorporates a comprehensive examination of eight prominent models based on the aforementioned behavioral intention schemes plus a small number of their extensions in a unified technology acceptance approach. The specific model comprises four independent key constructs, namely, performance expectancy, effort expectancy, social influence and facilitating conditions, as direct determinants of behavioral intention and use behavior [30]. These authors have also introduced individual differences-age, gender, experience and voluntariness of use-acting as moderators on the effect of the four independent key constructs on behavioral intention and technology use. Regarding its application in an AR adoption context, a small number of empirical studies took place. For instance, Shang et al. [42] proved the impact of performance expectancy and facilitating conditions on the adoption of a mobile AR app for historical monuments. Additionally, Paulo et al. [41] utilized the UTAUT in order to examine the adoption of AR in tourism. They proved that facilitating conditions and performance expectancy have an impact on the variable of behavioral adoption intention.

In this context, the present research is based on the UTAUT as it is considered the latest derivative of TAM and has already been widely applied in various technology adoption empirical studies. More specifically, the study maintains the major UTAUT key constructs-performance expectancy, effort expectancy, social influence, facilitating conditions and behavioral intention-and employs an additional set of four new variables used in the extant literature-innovativeness, trust, enjoyment and reward-which are likely to affect mobile AR for shopping, information and entertainment purposes. The significance of innovativeness, trust and enjoyment have already been approved in previous AR empirical studies (e.g., [18,25,40,46]). Their importance, however, for shopping, information and entertainment purposes in shopping malls have not been investigated so far. Moreover, reward was selected as it is considered as a key determinant in adopting a pioneer app that incorporates information and entertainment purposes. Likewise, the extension of the original UTAUT model with four additional variables is expected to provide a deeper examination of an individual's behavioral 
adoption intention towards mobile AR apps in shopping malls. It is worth noting that in the study all these determinants are used in a rigorous AR framework.

In summary, our research goal is to identify the parameters that drive individuals' behavioral intention to adopt mobile AR apps in shopping malls. As far as it is concerned, the study investigates a notable research gap in the pre-adoption stage of mobile AR apps in shopping malls. Based on the extended literature review and the development of an integrated conceptual framework, two research questions arise:

1. What factors impact individuals to adopt mobile AR apps in shopping malls?

2. What factors exert the greatest influence on individuals to adopt such mobile AR apps?

The research is organized in five sections. Section 2 includes the conceptual framework and research hypotheses, and is followed by a discussion of the research methodology and the results of the empirical study in Sections 3 and 4, respectively. Section 5 involves a discussion of the results, whereas last section deals with the conclusion of the study, its theoretical and managerial/practical implications, study'slimitations and makes relevant recommendations about future research.

\section{Conceptual Framework and Research Hypotheses}

Based on a comprehensive literature review, a proposed conceptual framework including a group of preliminary hypotheses is formulated (Figure 1). The framework includes the variables: performance expectancy, effort expectancy, social influence, facilitating conditions, behavioral intention, innovativeness, trust, enjoyment and reward. The specific section discusses the research hypotheses developed and provides explanations about the variables.

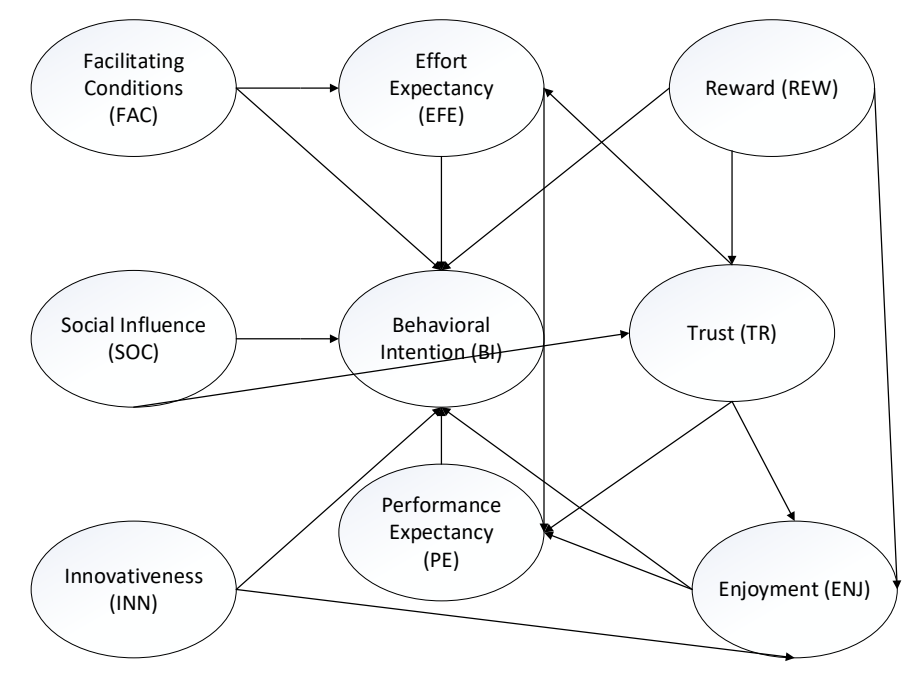

Figure 1. Conceptual Framework.

\subsection{Behavioral Intention}

The vast majority of the theories and models of behavioral intention, such as the Technology Adoption Model (TAM), the Theory of Reasoned Action (TRA) and Unified Theory of Acceptance and Use of Technology (UTAUT), which were previously mentioned, is focused on investigating the determinants affecting consumers towards adopting a relevant technology [47]. Fishbein and Ajzen [34] were the first to define the term "behavioral intention" and describe it as "a person's subjective probability that he/she will perform some behavior". Venkatesh et al. [30] were among the researchers who followed up and developed the UTAUT, which is finally associated with behavior. In this context, the conceptual framework discussed in the present research involves the factor "behavioral intention", which is used to describe "a person's subjective probability that he/she will use a mobile AR app in a shopping mall". 


\subsection{Performance Expectancy}

Performance expectancy, along with effort expectancy, are the two key predictors, derived from perceived usefulness and perceived ease of use in correspondence introduced in Davis' [43] TAM [48]. Performance expectancy is defined as "the degree to which using a technology will provide benefits to consumers in performing certain activities" ([49], p. 159), and frequently has the highest effect on individuals' intention to adopt innovation technologies [50]. It is regarded as the strongest UTAUT predictor [30]. Up to now, in the mobile environment, various researchers have confirmed the positive effect of performance expectancy on behavioral intention. For example, [50-52] established its impact on mobile banking services whereas [46] stated that performance expectancy has a positive impact on mobile payments. Based on the aforementioned studies, it is expected that individuals will use the mobile AR app in a shopping mall if they believe that it will have positive outcomes [53]. Therefore, these considerations lead to the first hypothesis.

Hypothesis 1 (H1). Performance expectancy has a positive effect on behavioral intention.

\subsection{Effort Expectancy}

Effort expectancy is a vital predictor of technology acceptance and is described as "the degree of ease associated with the use of the system" ([49], p. 159). Venkatesh et al. [30] argued that the antecedents of effort expectancy are ease of use, perceived ease of use and complexity. Based on this definition, individuals are more likely to express intention to adopt a technology when they perceive that this technology is simple to use and interaction is unambiguous and comprehensible [50]. In the mobile environment, various studies have proved the positive impact of effort expectancy on behavioral intention (e.g., [54-57]). On the other hand, the degree to which individuals perceive that a technology is easy to be learned affects their view of its usefulness, presenting effort expectancy as a determinant of performance expectancy [58]. Or et al. [59] mentioned that the higher effort expectancy, the less energy is perceived to be demanded to use and manage the technology. In addition, Cimperman et al. [58] demonstrated the positive effect of effort expectancy on performance expectancy. Therefore, it is hypothesized that:

Hypothesis 2 (H2). Effort expectancy has a positive effect on behavioral intention.

Hypothesis 3 (H3). Effort expectancy has a positive effect on performance expectancy.

\subsection{Social Influence}

Social influence is "the degree to which an individual perceives that significant others believe that he/she should use a particular technology" ([30], p. 451). Based on UTAUT, social influence has a direct positive effect on behavioral intention as it shapes potential users' attitude. As a result, studies predicting individuals' behavior in ICT acceptance state is a vital determinant since peers', family members' and friends' opinions have a serious impact on users' behavior (e.g., [48,59-61]). Individuals may have a more or less positive attitude towards accepting the technology, which depends on the degree at which the people who are important to them or influence their behavior urge them to use it [59]. The more positive the social support to adopt the technology the higher the individuals' intention to utilize ICT. In the mobile environment, various researchers have confirmed that social influence affects behavioral intention as well (e.g., [50-52,57,62-67]). On the other hand, Baabdullah [68] and Chaouali et al. [69] proved the positive impact of social influence on trust; in their studies on consumer's intention to adopt mobile social network games and internet banking services in correspondence. Therefore, it can also be argued that people who get positive influence from their close environment to use new technologies might have fewer restrictions. Hence, they might perceive that the technology is more trustful. Therefore, it is hypothesized that:

Hypothesis 4 (H4). Social influence has a positive influence on behavioral intention. 
Hypothesis 5 (H5). Social influence has a positive influence on trust.

\subsection{Facilitating Conditions}

The construct of facilitating conditions is defined as "the degree to which an individual believes that an organizational and technical infrastructure exists to support the use of the system" ([30], p. 453). Thus, this determinant involves the external factors that support individuals in adopting a novel IT [70]. To clarify, when individuals perceive that situations are ideal for adopting the technology, behaviors can occur [8]. With regard to the UTAUT model, the facilitating conditions have a positive relationship with user behavior but no direct impact on behavioral intention [30].

In the context of mobile environment, Baptist and Oliveira [51] and Krogstie [5] demonstrated this relationship, which in other studies is rejected. To illustrate, Bawack and Kamdjoug [71] and Cimperman et al. [58] argued that facilitating conditions have a direct impact on behavioral intention. On the other hand, there have been studies that revealed the positive impact of facilitating conditions on effort expectancy (e.g., [8,46,72]). As AR is a brand-new technology, facilitating conditions are necessary. For example, it is vital to examine if individuals have suitable mobile devices, which enable the use of AR apps, and also if they know how to use them. When these conditions are met, it is expected that they will use AR technologies more easily [8]. Thus, it can be hypothesized that:

Hypothesis 6 (H6). Facilitating conditions have a positive effect on behavioral intention.

Hypothesis 7 (H7). Facilitating conditions have a positive effect on effort expectancy.

\subsection{Innovativeness}

Users' innovativeness is considered a determinant of vital impact on ICT adoption (e.g., [73,74], and has, therefore, been examined and integrated in various well-established behavioral intention models and schemes (e.g., [75,76]). According to Agarwal and Prasad [77], the first researchers who introduced the innovativeness construct and its impact on ICT, AR is defined as "the willingness of an individual to try out any new IT" and is conceptualized as a trait, which is not affected by environmental or external variables. In the studies of technology acceptance, innovation is linked to the amount of interest in experimenting with pioneering goods or concepts [36].

In the context of mobile environments, various researchers have investigated its impact as well (e.g., [78,79]) and suggested that a user's level of innovativeness greatly affect technology adoption, in particular AR [18]. For example, Yi et al. [80] stated that mobile innovators have the talent to envision, comprehend and acknowledge the benefits linked with an innovation, thus, they have higher tolerance to risk and are expected to adopt or utilize the innovation [70,81]. Similarly, Tariq [82] proved that highly innovative people are constantly looking for fresh ideas; consequently, they can handle uncertainties and promote a positive attitude towards mobile IT adoption. Based on these studies, it can be argued that mobile AR app innovators will be the first to benefit from the functions of the shopping mall AR app. Therefore, the more innovative a mobile user is, the higher the chances to realize the fun and pleasure features provided by a mobile AR app. Hence, it can be hypothesized that:

Hypothesis 8 (H8). Innovativeness has a positive effect on behavioral intention.

Hypothesis 9 (H9). Innovativeness has a positive effect on enjoyment.

\subsection{Trust}

Various scientific fields have investigated trust and its research impact, including management, technology, economics, social and institutional contexts, and behavior and psychology [83]. As a result, various different definition approaches have been provided (e.g., [84-86]). Li et al. [85] characterized trust as asymmetric, dynamic, subjective, bi-directional, context-dependent and non-transitive. 
According to Roger's [36] DOI's view of the innovation-decision process, in the pre-adoption stage, it can be a key promotional activity to encourage consumers to be trustful for a new technology. Trust is critical in determining both individual's adoption intention and actual behavior [87-89]. Regarding the e-commerce environment, a number of researchers have already elaborated on its role and the vast majority of them believe that trust can be considered the basis of e-commerce [13] and one of the key factors for successful transactions [90]. Furthermore, in the mobile environment, because the insecurity concern is higher than e-commerce, the significance of trust is higher [91].

According to (Shin, [92], p. 1346), trust implies "the belief that vendors will perform some activity in accordance with customers' expectations". Based on this definition and the fact that it is a determinant of expectation, it is likely to deduce its effect on effort expectancy [63]. In addition, in the context of mobile AR, where various apps have been developed for fun and pleasure (e.g., games), it can be inferred that the higher the trust perceptions of an individual, the more chances he/she has to find them enjoyable. It is also worth noting that Khalilzadeh et al. [46] demonstrated the impact of trust on performance expectancy. Therefore, in the present study, "trust" implies "users' perceptions that the mobile AR app is trustworthy and that the app is also fully compliant with the terms of use". Thus, it is hypothesized that:

Hypothesis 10 (H10). Trust has a positive effect on performance expectancy.

Hypothesis 11 (H11). Trust has a positive effect on effort expectancy.

Hypothesis 12 (H12). Trust has a positive effect on enjoyment.

\subsection{Enjoyment}

Davis (1989) was among the first researchers who introduced enjoyment in a well-established behavioral intention model-TAM — as an intrinsic motivation [43]. More specifically, they defined it as "the extent to which the activity of using the computer is perceived to be enjoyable in its own right, apart from any performance consequences that may be anticipated" [43]. Concerning AR environment, there have been various studies that proved the impact of enjoyment on the adoption of an AR application. In detail, Haugstvedt and Krogstie [2] proved that enjoyment positively affect the adoption of a mobile AR app for cultural heritage and Ghazali et al. [1] its impact on an individual intention to play 'Pokemon Go'. Additionally, Olsson et al. [15] stated that information usefulness and its effect produce fun-enjoyment-in mobile AR services in shopping malls, and Balog and Pribeanu [45] argued that enjoyment positively affects perceived usefulness and behavioral intention in an AR teaching platform. Similarly, Rese et al. [25] proved its impact on perceived usefulness in IKEA's mobile catalogue AR app. Finally, according to Kim and Forsythe [18] and Mathwick et al. [93], AR technology boosts shopping experience with enjoyment and increases individual inclination to online purchases. Therefore, it is hypothesized that:

Hypothesis 13 (H13). Enjoyment has a positive effect on performance expectancy.

Hypothesis 14 (H14). Enjoyment has a positive effect on behavioral intention.

\subsection{Reward}

Contemporary marketing emphasizes the importance of firms and organizations to build strong relationships with consumers. Morgan [94] stated that distinctive competencies are key factors for a customer to feel committed to an enterprise or product. The unique features of the mobile technology, such as ubiquity, personalized information based on customers' location, time personalization settings and individual hobbies and interests are characterized as valuable assets for building strong relationships in the mobile environment. The fact that individuals can reach the information and apply 
mobile features any time [95-97], and everywhere [98,99] offers a strong advantage for location-based and time-sensitive content and services to be accessed via individuals' mobile devices at the point adapted to their personal identity $[95,98,100,101]$. Therefore, mobile AR apps in a shopping mall enable individuals to have a greater shopping experience because of the provided digital information when they search for an item in a shopping center. For example, a special offer notification, a limited time discount and/or a membership discount can convince consumers to purchase a product when entering a shopping mall. Jang et al. [102] emphasized the positive impact of discount coupons on continuous usage of social commerce sites. Furthermore, it can be argued that reward actions can make the provided app features more enjoyable. For example, the 'Pokemon Go' app has been greatly based on the reward features of its gameplay. It is also expected that the more satisfied from reward actions consumers are, the higher their trust feelings towards the mobile AR app will be. Thus, a user who is greatly benefited by the app will not hesitate to provide personal information, such as demographic or psychographic characteristics. Therefore, it is hypothesized that:

Hypothesis 15 (H15). Reward has a positive effect on enjoyment.

Hypothesis 16 (H16). Reward has a positive effect on behavioral intention.

Hypothesis 17 (H17). Reward has a positive effect on trust.

All research hypotheses of the proposed conceptual framework are presented on Table 1.

Table 1. Research Hypotheses.

\begin{tabular}{crc}
\hline Hypothesis & Description & Path \\
\hline H1 & Performance Expectancy has a positive influence on Behavioral Intention & PE $\rightarrow$ BI \\
\hline H2 & Effort Expectancy has a positive influence on Behavioral Intention & EFE $\rightarrow$ BI \\
\hline H3 & Effort Expectancy has a positive influence on Performance Expectancy & EFE $\rightarrow$ PE \\
\hline H4 & Social influence has a positive influence on Behavioral Intention. & SOC $\rightarrow$ BI \\
\hline H5 & Social influence has a positive influence on Trust & SOC $\rightarrow$ TR \\
\hline H6 & Facilitating conditions have a positive influence on Behavioral Intention & FAC $\rightarrow$ BI \\
\hline H7 & Facilitating conditions have a positive influence on Effort Expectancy & FAC $\rightarrow$ EFF \\
\hline H8 & Innovativeness has a positive influence on Behavioral Intention & INN $\rightarrow$ BI \\
\hline H9 & Innovativeness has a positive influence on Enjoyment & INN $\rightarrow$ ENJ \\
\hline H10 & Trust a positive influence on Performance Expectancy & TR $\rightarrow$ PE \\
\hline H11 & Trust has a positive influence on Effort Expectancy & TR $\rightarrow$ EFE \\
\hline H12 & Trust has a positive influence on Enjoyment & TR $\rightarrow$ ENJ \\
\hline H13 & Enjoyment has a positive influence on Performance Expectancy & ENJ $\rightarrow$ PE \\
\hline H14 & Enjoyment has a positive influence on Behavioral Intention & ENJ $\rightarrow$ BI \\
\hline H15 & Reward has a positive influence on Enjoyment & REW $\rightarrow$ ENJ \\
\hline H16 & Reward has a positive influence on Behavioral Intention & REW $\rightarrow$ BI \\
\hline H17 & Reward has a positive influence on Trust & REW $\rightarrow$ TR \\
\hline
\end{tabular}

\section{Methodology}

This section includes the operationalization of the research variable of the hypothesized conceptual framework, followed by data collection and sample characteristics. The last part of the section discusses the data analysis plan. 


\subsection{Determinants' Operationalization}

Table 2 depicts the research determinant definitions. For every determinant, a multiple-item scale was developed, according to comprehensive information in the literature review, and was measured in terms of a 5-point Likert scale. In detail, three items were applied to measure performance expectancy, effort expectancy, enjoyment, trust, social conditions, facilitating conditions and reward, whereas four items were applied to measure behavioral intention and innovativeness.

Table 2. Operational definition of research variables.

\begin{tabular}{|c|c|c|}
\hline Research Variables & Operational Definition & Sources \\
\hline \multirow{3}{*}{$\begin{array}{l}\text { Performance Expectancy } \\
\qquad(\mathrm{PE})\end{array}$} & $\begin{array}{l}\text { PE1: I think that using an AR app in a shopping mall would help me accomplish } \\
\text { tasks more quickly }\end{array}$ & \multirow{16}{*}{ Adapted from [30] } \\
\hline & $\begin{array}{l}\text { PE2: I think that using an AR app in a shopping mall would increase my chances } \\
\text { of achieving what is important to me }\end{array}$ & \\
\hline & PE3: I suppose an AR app in a shopping mall is useful & \\
\hline \multirow{3}{*}{$\begin{array}{l}\text { Effort Expectancy } \\
\quad \text { (EFE) }\end{array}$} & $\begin{array}{l}\text { EFE1: I think that learning how to use an AR app in a shopping mall would be easy } \\
\text { for me }\end{array}$ & \\
\hline & $\begin{array}{c}\text { EFE2: I think that it would be easy for me to be able to use an AR app in a } \\
\text { shopping mall }\end{array}$ & \\
\hline & EFE3: I think that I would find an AR app in a shopping mall easy to use & \\
\hline \multirow{3}{*}{$\begin{array}{l}\text { Social Influence } \\
\quad \text { (SOC) }\end{array}$} & $\begin{array}{l}\text { SOC1: People who are important to me think that I should use an AR app in a } \\
\text { shopping mall }\end{array}$ & \\
\hline & $\begin{array}{l}\text { SOC2: People who influence my behavior think that I should use an AR app in a } \\
\text { shopping mall }\end{array}$ & \\
\hline & $\begin{array}{l}\text { SOC3: People whose opinions I value prefer that I should use an AR app in a } \\
\text { shopping mall }\end{array}$ & \\
\hline \multirow{3}{*}{$\begin{array}{l}\text { Facilitating Conditions } \\
\qquad \text { (FAC) }\end{array}$} & $\begin{array}{l}\text { FAC1: I think that I have the proper smartphone to use an AR app in a shopping } \\
\text { mall }\end{array}$ & \\
\hline & $\begin{array}{l}\text { FAC2: I think that my knowledge of using an AR app in a shopping mall is } \\
\text { adequate }\end{array}$ & \\
\hline & $\begin{array}{l}\text { FAC3: I think that I can use an AR app in a shopping mall with my current } \\
\text { smartphone }\end{array}$ & \\
\hline \multirow{4}{*}{$\begin{array}{l}\text { Behavioral Intention } \\
\quad \text { (BI) }\end{array}$} & BI1: Given the chance, I am going to use an AR app in a shopping mall & \\
\hline & BI2: I intend to use an AP app in a shopping mall & \\
\hline & BI3: I expect I will use an AR app in a shopping mall in the future & \\
\hline & BI4: I will use an AR app if available in a shopping mall & \\
\hline \multirow{3}{*}{ Reward (REW) } & $\begin{array}{c}\text { REW1: I would use an AR app in a shopping mall if it provides information on } \\
\text { discounts }\end{array}$ & \multirow{3}{*}{$\begin{array}{l}\text { Adapted from } \\
{[56,76]}\end{array}$} \\
\hline & $\begin{array}{l}\text { REW2: I would use an AR app in a shopping mall if provides information on } \\
\text { special offers }\end{array}$ & \\
\hline & $\begin{array}{l}\text { REW3: I would use an AR app in a shopping mall if it provides me with loyalty } \\
\text { points and rewards }\end{array}$ & \\
\hline \multirow{3}{*}{ Enjoyment (ENJ) } & ENJ1: I think using an AR app in a shopping mall would be fun & \multirow{3}{*}{ Adapted from [30] } \\
\hline & ENJ2: I think using an AR app in a shopping mall would be a pleasure process & \\
\hline & ENJ3: I think using an AR app in a shopping mall would be enjoyable & \\
\hline \multirow{4}{*}{ Innovativeness (INN) } & INN1: I like using new technologies & \multirow{4}{*}{$\begin{array}{l}\text { Adapted from } \\
\quad[10,68]\end{array}$} \\
\hline & INN2: I like learning about new technologies & \\
\hline & $\begin{array}{l}\text { INN3: When I am informed about a new technological product, I try to find the } \\
\text { opportunity to experiment on it }\end{array}$ & \\
\hline & $\begin{array}{l}\text { INN4: Compared to my friends and family, I am usually among the first to try new } \\
\text { technologies }\end{array}$ & \\
\hline \multirow{3}{*}{ Trust (TR) } & TR1: I think that I would trust AR apps in a shopping mall & \multirow{3}{*}{ Adapted from [76] } \\
\hline & TR2: I think that a shopping mall AR app would be trustworthy & \\
\hline & $\begin{array}{l}\text { TR3: I think that I would strictly follow the terms of use while using an AR app in } \\
\text { a shopping mall }\end{array}$ & \\
\hline
\end{tabular}




\subsection{Data Collection and Sample Characteristics}

To examine the hypothesized conceptual framework (Figure 1), an anonymous e-questionnaire was developed and administered during a two-month period (April-May 2019). The measurement instrument was originally drafted in English, but it was intended for use in Greek. Thus, it was translated into Greek by a professional native English translator as well as researchers, working independently. The differences between the members of the working group were further examined and a final version of the Greek questionnaire was agreed upon. This final version was, then, translated back into English by a university English professor to ensure consistency between the Greek and English version of the measurement instrument.

The target group was university students from Greece who visit a mall for shopping and entertainment purposes at least once a month [103]. Sampling included university students has commonly successfully derived results in primary research in many studies (e.g., [104-106]). Furthermore, individuals in this age group are more keen on mobile apps and receptive to adopting a novel technology (e.g., [107,108]). The convenience sampling method was used because the population size is unknown for this study [74,109]. As regards the applied measurement items mentioned above, these are based on previous validity and reliability approval empirical studies. However, the e-questionnaire was reviewed and pre-tested by two researchers before distribution; a thirty-response sample enabled identifying potential clarity and accuracy constraints.

The e-questionnaire was developed on Google forms and students were asked via an e-mail to answer the questions. The e-questionnaire was distributed to 2300 academic e-mail accounts. In addition, it was accompanied by a detailed text and a video explaining in detail AR technology and the purpose of the study. Four-hundred-and-five students responded to it, with a response rate of $17.6 \%$. Twenty-four respondents, however, did not complete the measurement instrument and they were dropped from the sample. Therefore, the corpus of data of the empirical study includes answers from 381 students (Table 3).

Table 3. Demographics of the study participants $(n=381)$.

\begin{tabular}{ccc}
\hline Demographic Characteristics & Respondents & Percent (\%) \\
\hline Sex: & & \\
\hline Male & 229 & 60.1 \\
\hline Female & 152 & 39.9 \\
\hline University rank: & 190 & 49.9 \\
\hline Freshmen & 124 & 32.5 \\
\hline Sophomores & 29 & 7.6 \\
\hline Juniors & 17 & 4.5 \\
\hline Seniors & 21 & 5.5 \\
\hline Graduate student & 236 & 61.9 \\
\hline Place of residence: & 78 & 20.5 \\
\hline City ( $>10000$ inhabitants) & 67 & 17.6 \\
\hline Small town (2000-10000 inhabitants) & \\
\hline Village/Countryside (<2000 inhabitants) &
\end{tabular}

Table 3 demonstrates the respondents' demographic profile. The results show that $60.1 \%$ were male and $39.9 \%$ female. The majority $(82.4 \%)$ were 1 st and 2 nd year students. With regard to their place of residence and based on the Hellenic Statistical Authority places' classification [110], more than half of the respondents live in cities (61.9\%); followed by those living in a small town $(20.5 \%)$ and village/countryside (17.6\%). 


\subsection{Data Analysis Plan}

To examine the hypothesized framework, structural equation modeling (SEM) using maximum likelihood estimation was applied (Figure 1). SEM, which is comprised of a measurement model and a structural model, is suitable for examining the underlying hypothesized structural relations between the research independent and dependent variables (using estimated regression parameters). Even though using SEM in cross-sectional models cannot establish causal pathways, it is valuable for examining the relative fit of a given causal model to an existing data set.

In terms of measurement, the model allows us to estimate latent variables reflecting constructs of interest. Notably, measurement for all nine constructs was first assessed via Confirmatory Factor Analysis (CFA). In addition, the constructs were evaluated in terms of reliability and convergent and discriminant validity. Remarkably, convergent validity uses three recommended standards for assessing the measuring model: (1) all indicator factor loading values should exceed 0.4 [111]; (2) composite reliability (CR) should exceed 0.6 [112]; and (3) the average variance extracted (AVE) of each determinant must exceed 0.5 [113], when the specific measurement scale is used. In addition, discriminant validity was assessed by comparing the potential correlations between constructs with the square roots of AVE values [113]. To identify typical method bias and enable checking if data variance can be largely associated with a single factor, post hoc Harman's one factor analysis was performed [114].

Subsequently, the construct relationships were calculated in the framework of the structural model, which is examined to test the relationships between the theoretical determinants in terms of strength and direction. An overall goodness-of-fit model can be assessed employing a combination of measures. The basis for an adequately fitted model was a chi-square/df ratio less than five [115], adjusted goodness-of-fit index (AGFI), comparative fit index (CFI), normed fit index (NFI), incremental fit index (IFI) and Tucker-Lewis index (TLI) values greater than 0.90 [116], and a root mean square error of approximation (RMSEA) less than 0.05 [117].

\section{Results}

The result section involves a summary of the outcomes of the SEM framework applied to empirically test the hypothesized variable relationships. The specific section includes the development and testing of the measurement part of the model, followed by the structural model evaluation.

\subsection{Measurement Model}

The measurement model (i.e., Confirmatory Factor Analysis or CFA model) is comprised of 29 items, which describe the nine underlying constructs demonstrated in Table 3. The overall goodness-of-fit of the model was satisfactory (Table 4): chi square/df and RMSEA (Root Mean Square Error of Approximation) are less than the recommended values, whereas Goodness of Fit Index (GFI), Comparative Fit Index (CFI), Normed Fit Index (NFI), Incremental Fit Index (IFI) and Tucker-Lewis Index (TLI) are greater than the recommended threshold and Adjusted Goodness of Fit (AGFI) is very close to 0.9. The standardized indicator factor loadings for all observed indicators (Table 5) were all statistically significant and exceeded 0.4. Skewness and kurtosis values for all items were less than three, which revealed no significant departures from normality [118]. In addition, composite construct reliability (CR) ranged from 0.768 to 0.857 , above the recommended threshold of 0.6 . Cronbach's alpha values were also high in all cases $(>0.80)$. Average variance extracted (AVE) values were greater than the recommended 0.5 cut-off, ranging from 0.525 to 0.706 , which implies that all conditions for convergent validity were met. Table 6 demonstrates the square roots of AVE, which were all greater than inter-scale correlations (off-diagonal elements) in the corresponding rows and columns; therefore, discriminant validity was sustained. In addition, an inspection of modification indices did not suggest any substantially meaningful model revisions. 
Table 4. Evaluation of model goodness-of-fit.

\begin{tabular}{cccc}
\hline Measures & Recommended Value & Measurement Model & Structural Model \\
\hline$\chi^{2} / \mathrm{df}$ & $\leq 5.00$ & 1.934 & 1.599 \\
\hline GFI & $\geq 0.90$ & 0.895 & 0.911 \\
\hline AGFI & $\geq 0.90$ & 0.866 & 0.892 \\
\hline CFI & $\geq 0.90$ & 0.959 & 0.972 \\
\hline NFI & $\geq 0.90$ & 0.919 & 0.930 \\
\hline IFI & $\geq 0.90$ & 0.959 & 0.973 \\
\hline TLI & $\geq 0.90$ & 0.951 & 0.968 \\
\hline RMSEA & $\leq 0.05$ & 0.05 & 0.040 \\
{$[90 \% C I]$} & & $0.044,0.055]$ & {$[0.034,0.046]$} \\
\hline
\end{tabular}

Table 5. Standardized factor loadings and individual item reliability.

\begin{tabular}{|c|c|c|c|c|c|c|c|}
\hline Construct & Item & Loading & Skewness & Kurtosis & CR & AVE & Cronbach's Alpha \\
\hline \multirow{3}{*}{$\begin{array}{l}\text { Performance } \\
\text { Expectancy (PE) }\end{array}$} & 1 & 0.789 & -0.864 & 0.583 & \multirow{3}{*}{0.804} & \multirow{3}{*}{0.579} & \multirow{3}{*}{0.870} \\
\hline & 2 & 0.824 & -0.765 & 0.310 & & & \\
\hline & 3 & 0.661 & -0.921 & 0.613 & & & \\
\hline \multirow{3}{*}{ Effort Expectancy (EFE) } & 1 & 0.718 & -0.834 & 0.686 & \multirow{3}{*}{0.804} & \multirow{3}{*}{0.578} & \multirow{3}{*}{0.836} \\
\hline & 2 & 0.817 & -0.887 & 0.493 & & & \\
\hline & 3 & 0.742 & -0.721 & 0.284 & & & \\
\hline \multirow{3}{*}{ Social Influence (SOC) } & 1 & 0.838 & -0.968 & 0.557 & \multirow{3}{*}{0.857} & \multirow{3}{*}{0.667} & \multirow{3}{*}{0.873} \\
\hline & 2 & 0.803 & -0.759 & 0.045 & & & \\
\hline & 3 & 0.808 & -0.894 & 0.567 & & & \\
\hline \multirow{3}{*}{$\begin{array}{l}\text { Facilitating Conditions } \\
\text { (FAC) }\end{array}$} & 1 & 0.902 & -1.349 & 1.072 & \multirow{3}{*}{0.801} & \multirow{3}{*}{0.589} & \multirow{3}{*}{0.804} \\
\hline & 2 & 0.461 & -0.946 & 0.344 & & & \\
\hline & 3 & 0.861 & -1.462 & 1.792 & & & \\
\hline \multirow{4}{*}{$\begin{array}{l}\text { Behavioral Adoption } \\
\text { (BA) }\end{array}$} & 1 & 0.590 & -0.943 & 0.258 & \multirow{4}{*}{0.802} & \multirow{4}{*}{0.675} & \multirow{4}{*}{0.916} \\
\hline & 2 & 0.738 & -0.709 & -0.172 & & & \\
\hline & 3 & 0.795 & -0.659 & -0.172 & & & \\
\hline & 4 & 0.707 & -0.730 & 0.050 & & & \\
\hline \multirow{3}{*}{ Reward (REW) } & 1 & 0.767 & -1.094 & 0.710 & \multirow{3}{*}{0.824} & \multirow{3}{*}{0.610} & \multirow{3}{*}{0.885} \\
\hline & 2 & 0.781 & -1.135 & 0.780 & & & \\
\hline & 3 & 0.795 & -0.844 & -0.163 & & & \\
\hline \multirow{3}{*}{ Enjoyment (ENJ) } & 1 & 0.754 & -0.652 & 0.077 & \multirow{3}{*}{0.787} & \multirow{3}{*}{0.552} & \multirow{3}{*}{0.920} \\
\hline & 2 & 0.758 & -0.538 & -0.145 & & & \\
\hline & 3 & 0.716 & -0.592 & -0.040 & & & \\
\hline \multirow{4}{*}{ Innovativeness (INN) } & 1 & 0.716 & -1.133 & 0.936 & \multirow{4}{*}{0.818} & & \\
\hline & 2 & 0.690 & -1.342 & 1.626 & & & \\
\hline & 3 & 0.760 & -0.419 & -0.383 & & 0.706 & 0.843 \\
\hline & 4 & 0.743 & -0.418 & -0.649 & & & \\
\hline & 1 & 0.749 & -0.129 & -0.137 & & & \\
\hline Trust (TR) & 2 & 0.749 & -0.209 & -0.281 & 0.768 & 0.525 & 0.826 \\
\hline & 3 & 0.674 & -0.462 & -0.452 & & & \\
\hline
\end{tabular}


Table 6. Inter-correlations and square roots of average variance extracted.

\begin{tabular}{cccccccccc}
\hline & $\mathbf{1}$ & $\mathbf{2}$ & $\mathbf{3}$ & $\mathbf{4}$ & $\mathbf{5}$ & $\mathbf{6}$ & $\mathbf{7}$ & $\mathbf{8}$ & $\mathbf{9}$ \\
\hline PE (1) & 0.76 & & & & & & & & \\
\hline EFE (2) & 0.65 & 0.76 & & & & & & & \\
\hline SOC (3) & 0.39 & 0.59 & 0.82 & & & & & & \\
\hline FAC (4) & 0.31 & 0.47 & 0.47 & 0.77 & & & & & \\
\hline BI (5) & 0.78 & 0.56 & 0.48 & 0.37 & 0.82 & & & & \\
\hline REW (6) & 0.52 & 0.50 & 0.52 & 0.46 & 0.66 & 0.78 & & & \\
\hline ENJ (7) & 0.64 & 0.55 & 0.47 & 0.38 & 0.78 & 0.61 & 0.74 & & \\
\hline INN (8) & 0.49 & 0.52 & 0.43 & 0.45 & 0.62 & 0.61 & 0.66 & 0.84 & \\
\hline TR (9) & 0.61 & 0.57 & 0.52 & 0.43 & 0.67 & 0.60 & 0.67 & 0.59 & 0.72 \\
\hline
\end{tabular}

Note: The diagonal elements show the square root of the average variance extracted. The off-diagonal elements show the correlations between the constructs, all significant at 0.01 level.

\subsection{Structural Model}

After correctly specifying the measurement model, the structural model (Figure 1) was expected to provide an empirical measure of the hypothesized relationships among the research variables and constructs; standardized parameters are shown, solid lines signify major pathways and correlations between constructs are not shown for clarity. In addition, inspection of the goodness-of-fit measures demonstrated a good model fit (see Table 4).

The path diagram with the resulting standardized regression coefficients indicating the direction and magnitude of relationships among variables is demonstrated in Figure 2. The structural model reveals that only four of the 17 hypotheses were rejected (Table 7). The exceptions involve the direct effects of effort expectancy, social influence, facilitating conditions and innovativeness on behavioral adoption $(\mathrm{H} 2, \mathrm{H} 4, \mathrm{H} 6$ and $\mathrm{H} 8)$. In contrast, as expected, performance expectancy has a strong positive effect on behavioral adoption $(\mathrm{H} 1 ; \beta=0.43, p<0.001)$ and effort expectancy a strong positive impact on performance expectancy $(\mathrm{H} 3 ; \beta=0.34, p<0.001)$. In addition, social influence has a high positive effect on trust (H5; $\beta=0.29, p<0.001)$, thus, supporting our hypothesis. Facilitating conditions revealed an impact on effort expectancy (H7; $\beta=0.54, p<0.001)$ and innovativeness a positive effect on enjoyment (H9; $\beta=0.43$, $p<0.001)$. Trust also demonstrated a positive effect on performance expectancy (H10; $\beta=0.21, p<0.01)$, effort expectancy (H11; $\beta=0.31, p<0.001)$ and enjoyment $(\mathrm{H} 12 ; \beta=0.39, p<0.001)$ as anticipated, and enjoyment has a positive effect on performance expectancy (H13; $\beta=0.33, p<0.001)$ and behavioral adoption (H14; $\beta=0.43, p<0.001)$. Finally, reward proved to have a positive effect on enjoyment (H15; $\beta=0.17, p<0.05)$, behavioral adoption (H16; $\beta=0.22, p<0.001$ ) and trust $(\mathrm{H} 17 ; \beta=0.46, p<0.001)$.

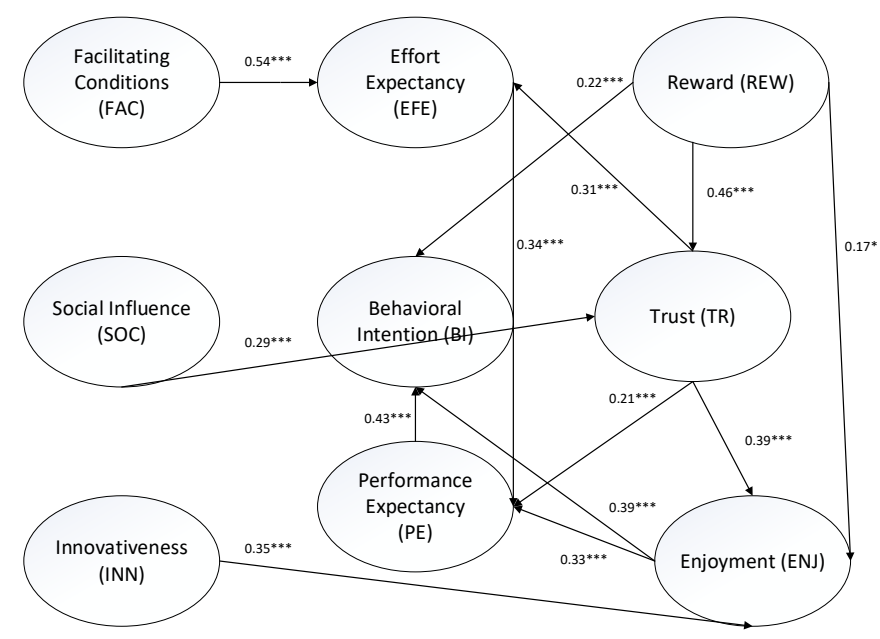

Figure 2. Results of the structural equation modelling. ${ }^{*} p<0.05 .{ }^{* * *} p<0.001$. 
Table 7. Path coefficients (standardized regression coefficients).

\begin{tabular}{|c|c|c|}
\hline Hypothesis & Path & Coefficient \\
\hline H1 & $\mathrm{PE} \rightarrow \mathrm{BI}$ & $0.43^{* * *}$ \\
\hline $\mathrm{H} 2$ & $\mathrm{EFE} \rightarrow \mathrm{BI}$ & Non-Significant \\
\hline $\mathrm{H} 3$ & $\mathrm{EFE} \rightarrow \mathrm{PE}$ & $0.34^{* * *}$ \\
\hline $\mathrm{H} 4$ & $\mathrm{SOC} \rightarrow \mathrm{BI}$ & Non-Significant \\
\hline H5 & $\mathrm{SOC} \rightarrow \mathrm{TR}$ & $0.29 * * *$ \\
\hline H6 & $\mathrm{FAC} \rightarrow \mathrm{BI}$ & Non-Significant \\
\hline H7 & $\mathrm{FAC} \rightarrow \mathrm{EFF}$ & $0.54^{* * *}$ \\
\hline $\mathrm{H} 8$ & $\mathrm{INN} \rightarrow \mathrm{BI}$ & Non-Significant \\
\hline $\mathrm{H} 9$ & $\mathrm{INN} \rightarrow \mathrm{ENJ}$ & $0.43^{* * *}$ \\
\hline H10 & $\mathrm{TR} \rightarrow \mathrm{PE}$ & $0.21^{* *}$ \\
\hline H11 & $\mathrm{TR} \rightarrow \mathrm{EFE}$ & $0.31^{* * *}$ \\
\hline H12 & $\mathrm{TR} \rightarrow \mathrm{ENJ}$ & $0.39 * * *$ \\
\hline H13 & $\mathrm{ENJ} \rightarrow \mathrm{PE}$ & $0.33^{* * *}$ \\
\hline H14 & $\mathrm{ENJ} \rightarrow \mathrm{BI}$ & $0.43^{* * *}$ \\
\hline H15 & $\mathrm{REW} \rightarrow \mathrm{ENJ}$ & $0.17 *$ \\
\hline H16 & $\mathrm{REW} \rightarrow \mathrm{BI}$ & $0.22 * * *$ \\
\hline H17 & $\mathrm{REW} \rightarrow \mathrm{TR}$ & $0.46^{* * *}$ \\
\hline
\end{tabular}

\section{Discussion}

The research results suggest an enhanced acceptance model of a mobile AR app intention. It is worth noting, however, that in the proposed conceptual framework not all originally formulated hypotheses are verified. The structural model estimation indicates that 13 out of 17 hypotheses were supported (Table 7). The exceptions are the direct effects of effort expectancy (H2), social influence (H4), facilitating conditions (H6) and innovativeness (H8) on behavioral intention. Although the rejections of effort expectancy and social influence on behavioral intention are opposed to the principles of the original UTAUT model, this came as no surprise. In detail, the enhancement of the model with four additional variables has changed constructs' dynamics. Thus, in the enriched conceptual model, effort expectancy (H3) and social influence (H5) exert an indirect effect on behavioral intention (Figure 2). These findings are contingent with the Paulo et al. (2018) and Shang et al. (2017) empirical mobile AR studies, which revealed that effort expectancy and social influence do not directly affect behavioral intention [41,42]. However, performance expectancy (H1), enjoyment (H14) and reward (H16) exert a strong positive effect on behavioral intention. Specifically, the direct impact of performance expectancy on behavioral intention has already been approved in various mobile commerce studies e.g., [46,50-52], but not in the mobile AR context. Therefore, the confirmation of $\mathrm{H} 1$ could be considered as noteworthy concerning the further investigation of mobile AR technology for shopping and information purposes. With regards to enjoyment, the results actually confirmed a number of previous research studies which proved the impact of enjoyment in the behavioral intention of mobile AR applications in fields other than shopping malls, such as cultural heritage [2], education [45] and game industries [1]. Lastly, the literature mentioned the importance of reward in e-commerce [102]. Commonly, this study verified its importance in the mobile AR context as well.

In addition, reward has a significant positive effect on enjoyment (H15) and trust (H17), whereas trust affects effort expectancy (H11) and enjoyment (H12). The latter findings are contingent with Shin's [63] and Alalwan et al.'s [92] speculations. Furthermore, enjoyment was found to affect performance expectancy (H13), thereby supporting the specific research hypothesis, as well as previous 
researchers who investigated mobile AR, such as Olsson et al. [45] and Rese et al. [25]. Commonly, effort expectancy (H3) and trust (H10) were proven to impact performance expectancy. It is worth noting, however, that both of these hypotheses were never confirmed in the context of mobile AR. In conclusion, social influence proved to have a positive impact on trust (H5), and facilitating conditions on effort expectancy (H7). Finally, innovativeness was found to positively affect enjoyment (H9). None of these hypotheses (H5, H7 and H9) have ever been confirmed before in the AR literature.

\section{Conclusions}

Augmented Reality (AR), as an interactive technology, is a persuasive innovation, which greatly affects individuals [119]. Notably, it is a vital innovation that offers users' an interactive simulation experience rather than a set of usage technology functions [20]. Because of its comprehensive nature in utilitarian and hedonic values, AR experience could aid individuals in changing attitudes and boosting persuasion and motivation effects [119]. Thus, apart from delivering product information, rigorously similar to the information obtained from inspecting a product in order to reduce product acquisition risk, AR also offers a multisensory simulation experience, namely visual and haptic features, to enhance the playful shopping and entertainment experience [20]. It is perceived to be a persuasive technology creating and delivering experiential value rather than a functional technology $[19,119]$. From this perspective, Fiore et al. [33] emphasized that AR provides both utilitarian and hedonic values, which activate consumers' willingness to adopt its technological solutions.

In addition, nowadays, people tend to keep their mobile devices within arm's reach at all times. Remarkably, they use it to surf on the Internet more than any other networking device, which implies that smartphones are an individual's most trusted and important device. The aforementioned evidence, combined with lifestyles, according to which the vast majority of consumers prefer shopping and spending their leisure time in shopping malls, places a greater emphasis to the survey subject.

In this context, the present study investigates how behavioral intention, performance expectancy, effort expectancy, social influence, facilitating conditions, innovativeness, trust, enjoyment and reward co-exist in the same model and predict individuals' behavioral intention to use mobile AR apps for shopping, information and entertainment purposes. As research on technology acceptance in the context of AR in shopping malls has been poor so far, the findings of the present research offer substantial evidence in support of the specific AR model. The results demonstrate that performance expectancy and enjoyment are the most significant variables positively affecting behavioral intention. Remarkably, all examined variables are identified as significant factors affecting users' decisions to adopt a mobile AR app in a shopping mall, as well as their behavioral intention in either a direct or indirect way.

\subsection{Theoretical Implications}

The contribution of the specific research in various theoretical aspects of AR is multiple. Firstly, it helps develop a theoretical and conceptual framework to examine its effect on individuals' intention to adopt a mobile AR app in shopping malls, as it elaborates on the extant literature of the behavioral intention theory. The concomitant combination of determinants, used as parameters to predict individuals' behavior towards mobile AR apps for shopping and entertainment, as far as it is concerned, has not been investigated before. To be more specific, a number of determinants have already been explored separately, or as parts of other paradigms, whereas the framework discussed in the survey provides a comprehensive approach to the topic and extends a renowned Information Technology behavioral theory: UTAUT. Furthermore, a considerable number of interactions between the examined factors/variables were confirmed for the first time in the context of mobile AR. Their approval might offer vital insights to other academics and researchers who want to examine the mobile AR phenomenon. To add to this, the paper presents new insights about AR adoption as the survey was carried out in a country where AR technology has been poorly researched. 
Therefore, the proposed conceptual framework, along with the confirmation and rejection of its research hypotheses, could be used as a guide from the academic community who wants to further investigate the topic. Moreover, the proposed framework could be applied in other areas of interest where AR via mobile devices can be applied for shopping, information or entertainment purposes, such as traditional stores, points of interest, etc. Furthermore, additional factors could be adjusted to the framework with the aim to investigate other parameters that might impact individuals' behavioral intention to adopt a mobile AR app.

\subsection{Managerial and Practical Implications}

Accordingly, the implications of the research results are significant for practitioners, particularly application developers, mobile marketing managers, mobile product/service providers and researchers, who are keen on investigating users' technology acceptance models and behavior in mobile AR contexts. Furthermore, the results are expected to help shopping mall enterprises and managers to formulate target-oriented business strategies in order to offer a better shopping and entertainment experience to consumers, as well as more accurate and up-to-date information via the implementation of such mobile apps. Moreover, paper's outcomes may offer retailers a different perspective in their effort to attract customers and enhance their shopping experience. Additionally, it might force shopping malls and their retailers to engage in continuous IT and business transformations, as well as follow trends with the aim of complying with consumers' adoption of new technological innovations, and thus, modifying their shopping and entertainment behaviors.

Moreover, the applied conceptual framework employs perspectives from marketing to explore an aspect of technology acceptance and includes newly examined factors, such as enjoyment and reward. It also explores possible marketing solutions related to mobility characteristics and AR potential. In detail, enjoyment demonstrated a positive impact on behavioral intention and performance expectancy. Remarkably, mobile solution companies should exploit the bonds between mobile AR activities and users, via personalized information, which is optional and can be accessed anytime at any place by consumers when visiting a shopping mall and using the app. Therefore, such apps should be equipped with functions enhancing users' fun and pleasure feelings. To illustrate, viewers of IKEA's AR catalogue can accelerate decision-making processes by dragging an item from the catalogue, placing it anywhere in the simulated space on their mobile device and immediately taking a screenshot of that selection, which will enhance enjoyment and convenience [120]. In addition, reward has a positive impact on behavioral intention. The idea of correlating the adoption intention of an AR app in shopping malls with the relationship ties including special offers, discounts, loyalty points and location-based marketing activities, likely to be created by their own use, is groundbreaking and involves very specialized features of the specific technology. Such consumers normally relate the shopping process in a mall with an innovative money and time-saving shopping channel [121]. This explains why reward has been found to be a positive factor affecting behavioral intention.

Overall, the survey conclusions can provide valuable insights into how mobile AR apps should be developed to align with users' behavioral intention in shopping malls. Thus, enterprises engaging in mobile applications, $\mathrm{m}$-commerce and mobile marketing could exploit the research findings as a support tool when organizing mobile strategies and implementing such apps in order to motivate shopping mall visitors to use their special features and potential. To encourage adoption of such apps, they should provide significant incentives [122] and ensure that the technology offers unique benefits and values [123].

\subsection{Limitations and Future Study}

Despite the aforementioned results, which provide meaningful implications, the research can be further enhanced by overcoming a number of crucial limitations. First, further evidence from heterogeneous samples will ensure that the observed relationships are similar across different demographic characteristics such as gender, age groups, education, income, residence, occupation or 
family status. This examination may bring out valuable information. In other words, it may reveal additional evidence why effort expectancy, social influence and facilitating conditions do not directly affect behavioral intention. Second, relevant studies could be organized in other countries, focusing on the different cultural attitudes and drawing comparative data for a cross-cultural study. As the users' cultural background is one of the aspects which can contribute to creating a favorable context for developing and consolidating such AR apps, it is considered that further research would involve contrasting the validity of the proposed behavioral framework with samples from other cultures and comparing the relevant results. Such a process could be highly constructive for the mobile AR industry which is focused on developing multicultural apps for shopping and entertainment purposes.

There is no doubt that AR technology is here to stay and is about to greatly affect the shopping and entertainment experience in malls around the globe in the very near future.

Author Contributions: V.S.: Conceptualization, methodology, validation, formal analysis, investigation, resources, writing_-original draft preparation, writing_-review and editing, supervision. G.A.: Methodology, validation, data curation, writing-review and editing. A.K.: Formal analysis, writing-review and editing. All authors have read and agreed to the published version of the manuscript.

Funding: The project has been funded by the Research Committee of the University of Western Macedonia, Greece.

Conflicts of Interest: The authors declare no conflict of interest. Moreover, The funders had no role in the design of the study; in the collection, analyses, or interpretation of data; in the writing of the manuscript, or in the decision to publish the results.

\section{References}

1. Ghazali, E.; Mutum, S.D.; Woon, M.-Y. Exploring player behavior and motivations to continue playing Pokemon Go. Inf. Technol. People 2019, 32, 646-667. [CrossRef]

2. Haugstvedt, A.-C.; Krogstie, J. Mobile augmented reality for cultural heritage: A technology acceptance study. In Proceedings of the IEEE International Symposium on Mixed and Augmented Reality, Atlanta, GA, USA, 5-8 November 2012.

3. Olsson, T.; Salo, M. Online user survey on current mobile augmented reality applications. In Proceedings of the 10th IEEE International Symposium on Mixed and Augmented Reality, Basel, Switzerland, 26-29 October 2011; pp. 75-84.

4. Billinghurst, M.; Dunser, A. Augmented reality in the classroom. IEEE Comput. 2012, 45, 56-63. [CrossRef]

5. Krogstie, J. Bridging research and innovation by applying living labs for design science research. Nord. Contrib. IS Res. 2012, 159-176.

6. Wingfield, N.; Isaac, M. Google and Facebook Take Aim at Fake News Sites. The New York Times. Available online: https://www.nytimes.com/2016/07/12/technology/pokemon-go-brings-augmented-realityto-a-mass-audience.html?_r=1 (accessed on 9 September 2019).

7. van Boom, D. Pokemon Go has Crossed 1 Billion in Downloads. Available online: https://www.cnet.com/ news/pokemon-go-has-crossed-1-billion-in-downloads (accessed on 12 September 2019).

8. Chung, N.; Han, H.; Joun, Y. Tourists' intention to visit a destination: The role of augmented reality (AR) application for a heritage site. Comput. Hum. Behav. 2015, 50, 588-599. [CrossRef]

9. $\mathrm{He}, \mathrm{Z}$; $\mathrm{Wu}, \mathrm{L} . ; \mathrm{Li}, \mathrm{X} . \mathrm{-R}$. When art meets tech: The role of augmented reality in enhancing museum experiences and purchase intentions. Tour. Manag. 2018, 68, 127-139. [CrossRef]

10. Jung, T.; Chung, N.; Leue, M.C. The determinants of recommendations to use augmented reality technologies: The case of a Korean theme park. Tour. Manag. 2015, 49, 75-86. [CrossRef]

11. Kang, M.J.-Y. Augmented reality and motion capture apparel e-shopping values and usage intention. Int. J. Cloth. Sci. Technol. 2014, 26, 486-499. [CrossRef]

12. Kourouthanassis, P.; Boletsis, C.; Bardaki, C. Tourists responses to mobile augmented reality travel guides: The role of emotions on adoption behavior. Pervasive Mob. Comput. 2015, 18, 71-87. [CrossRef]

13. Lee, J.; Ryu, H.M.; Lee, D. A study on the reciprocal relationship between user perception and retailer perception on the platform-based mobile payment service. J. Retail. Consum. Serv. 2019, 48, 7-15. [CrossRef] 
14. Lum, R. Unilever Uses Augmented Reality (AR) To Spread Digital Romance. Available online: http://www.creativeguerrillamarketing.com/augmented-reality/unilever-uses-augmentedreality-ar-tospread-digital-romance (accessed on 7 March 2014).

15. Olsson, T.; Lagerstam, E.; Karkkainen, T.; Vaananen-Vainio-Mattila, K. Expected user experience of mobile augmented reality services: A user study in the context of shopping centers. Pers. Ubiquitous Comput. 2013, 17, 287-304. [CrossRef]

16. van Krevelen, D.W.F.; Poelman, R. A survey of augmented reality technologies, applications and limitations. Int. J. Virtual Real. 2010, 9, 1-20. [CrossRef]

17. Forbes Agency Council. 11 Creative Uses of Augmented Reality in Marketing and Advertising. Available online: https://www.forbes.com/sites/forbesagencycouncil/2017/06/13/11-creative-uses-of-augmented-reality-inmarketing-and-advertising/\#72488fb86b12 (accessed on 31 July 2017).

18. Kim, J.; Forsythe, S. Adoption of virtual try-on technology for online apparel shopping. J. Interact. Mark. 2008, 22, 45-59. [CrossRef]

19. McCarthy, J.; Wright, P. Technology as Experience; The MIT Press: Cambridge, MA, USA, 2004.

20. Huang, T.-L.; Liao, S. A model of acceptance of augmented-reality interactive technology: The moderating role of cognitive innovativeness. Electron. Commer. Res. 2015, 15, 269-295. [CrossRef]

21. Yovcheva, Z.; Buhalis, D.; Gatzidis, C. Overview of smartphone augmented reality applications for tourism. E-Rev. Tour. Res. 2012, 10, 63-66.

22. Karpischek, S.; Michahelles, F. my2cents-Digitizing consumer opinions and comments about retail products. In Proceedings of the Internet of Things (IOT), Tokyo, Japan, 29 November-1 December 2010.

23. Lee, K. Augmented reality in education and training. TechTrends 2012, 56, 13-21. [CrossRef]

24. Martínez, H.; Skournetou, D.; Hyppölä, J.; Laukkanen, S.; Heikkilä, A. Drivers and bottlenecks in the adoption of augmented reality applications. J. Multimed. Theory Appl. 2014, 1, 27-44. [CrossRef]

25. Rese, A.; Schreiber, S.; Baier, D. Technology acceptance modeling of augmented reality at the point of sale: Can surveys be replaced by an analysis of online reviews? J. Retail. Consum. Serv. 2014, 21, 869-876. [CrossRef]

26. Bojórquez, M.E.; Villegas, V.O.O.; Sánchez, C.V.G.; García-Alcaraz, L.J.; Vara, F.J. Study on mobile augmented reality adoption for Mayo language learning. Mob. Inf. Syst. 2016, 2016, 1-15. [CrossRef]

27. Javornik, A.; Rogers, Y.; Moutinho, A.M.; Freeman, R. Revealing the shopper experience of using a 'magic mirror' augmented reality make-up application. In Proceedings of the ACM Conference on Designing Interactive Systems, Brisbane, Australia, 4-8 June 2016.

28. Rauschnabel, A.P.; Ro, K.Y. Augmented reality smart glasses: An investigation of technology acceptance drivers. Int. J. Technol. Mark. 2016, 11, 123-148. [CrossRef]

29. Harborth, D.; Pape, S. Investigating privacy concerns related to mobile augmented reality applications. In Proceedings of the Fortieth International Conference on Information Systems, Munich, Germany, 15-18 December 2019; pp. 1-9.

30. Venkatesh, V.; Morris, M.G.; Hall, M.; Davis, G.B.; Davis, F.D.; Walton, S.M. User acceptance of information technology: Toward a unified view. MIS Q. 2003, 27, 425-478. [CrossRef]

31. Alkhamisi, A.O.; Monowar, M.M. Rise of Augmented Reality: Current and Future Application Areas. Int. J. Internet Distrib. Syst. 2013, 1, 25-34. [CrossRef]

32. Bulearca, M.; Tamarjan, D. Augmented Reality: A Sustainable Marketing Tool? Glob. Bus. Manag. Res. Int. J. 2010, 2, 237-252.

33. Fiore, A.M.; Kim, J.; Lee, H.-H. Effects of image interactivity on approach responses towards an online retailer. J. Interact. Mark. 2005, 19, 38-53. [CrossRef]

34. Fishbein, M.; Ajzen, I. Belief, Attitude, Intention and Behavior: An Introduction to Theory and Research; Addison-Wesley: Reading, MA, USA, 1975.

35. Ajzen, I. Theory of planned behavior. Organ. Behav. Hum. Decis. Process. 1991, 50, 179-211. [CrossRef]

36. Rogers, E.M. Diffusion of Innovations, 3rd ed.; Free Press: New York, NY, USA, 2003.

37. Ayeh, J.; Au, N.; Law, R. Towards an Understanding of Online Travllers' Acceptance of Consumer-Generated Media for Travel Planning: Integrating Technology Acceptance and Source Credibility Factors; Cantoni, L., Xiang, Z., Eds.; Information and Communication Technologies in Tourism; Springer: Heidelberg, Germany, 2013; pp. 254-267. 
38. Wu, K.; Zhao, Y.; Zhu, Q.; Tan, X.; Zheng, H. A meta-analysis of the impact of trust on technology acceptance model: Investigation of moderating influence of subject and context type. Int. J. Inf. Manag. 2011, 31, 572-581. [CrossRef]

39. Marangunić, N.; Granić, A. Technology acceptance model: A literature review from 1986 to 2013. Univers. Access Inf. Soc. 2015, 14, 81-95. [CrossRef]

40. Leue, M.C.; Dieck, T.D.; Jung, T. A theoretical model of augmented reality acceptance. Ereview Tour. Res. 2014, 5, 1-5.

41. Paulo, M.M.; Rita, P.; Oliveira, T.; Moro, S. Understanding mobile augmented reality adoption in a consumer context. J. Hosp. Tour. Technol. 2018, 9, 142-157. [CrossRef]

42. Shang, W.L.; Siang, G.T.; Zakaria, M.F.; Emran, H.M. Mobile augmented reality applications for heritage preservation in UNESCO world heritage sites through adopting the UTAUT model. In Proceedings of the AIP Conference, Bydgoszcz, Poland, 9-11 May 2017; Volume 1830, p. 30003.

43. Davis, F.D. Perceived usefulness, perceived ease of use, and user acceptance of information technology. MIS Q. 1989, 13, 319-340. [CrossRef]

44. Hong, S.; Thong, J.; Tam, K. Understanding continued information technology usage behavior: A Comparison of three models in the context of Mobile Internet. Decis. Support Syst. 2006, 42, 1819-1834. [CrossRef]

45. Balog, A.; Pribeanu, C. The role of perceived enjoyment in the student's acceptance of an augmented reality teaching platform: A structural equation modelling approach. Stud. Inform. Control 2010, 19, 319-330. [CrossRef]

46. Khalilzadeh, J.; Ozturk, A.B.; Bilgihan, A. Security-related factors in extended utaut mode for nfc based mobile payment in the restaurant industry. Comput. Hum. Behav. 2017, 70, 460-474. [CrossRef]

47. Wu, J.; Wang, S. What drives mobile commerce? An empirical evaluation of the revised technology acceptance model. Inf. Manag. 2005, 42, 719-729. [CrossRef]

48. Kim, J.; Park, H.-A. Development of a health information technology acceptance model using consumers' health behavior intention. Int. J. Med Inform. 2012, 14, e133. [CrossRef]

49. Venkatesh, V.; Thong, J.Y.; Xu, X. Consumer acceptance and use of information technology: Extending the unified theory of acceptance and use of technology. MIS Q. 2012, 36, 157-178. [CrossRef]

50. Giovanis, A.; Assimakopoulos, C.; Sarmaniotis, C. Adoption of mobile self-service retail banking technologies: The role of technology, social, channel and personal factors. Int. J. Retail Distrib. Channel 2018, 47, 894-914. [CrossRef]

51. Baptista, G.; Oliveira, T. Why so serious? Gamification impact in the acceptance of mobile banking services. Internet Res. 2017, 27, 118-139. [CrossRef]

52. Yu, C.-S. Factors affecting individuals to adopt mobile banking: Empirical evidence from the utaut model. J. Electron. Commer. Res. 2012, 13, 104-121.

53. Compeau, D.; Higgins, C. Computer self-efficacy: Development of a measure and initial test. MIS Q. 1995, 19, 189-211. [CrossRef]

54. Bhatiasevi, V. An extended UTAUT model to explain the adoption of mobile banking. Inf. Dev. 2016, 32, 799-814. [CrossRef]

55. Ntsafack, F.W.; Kamdjoug, J.R.K.; Wamba, S.F. Exploring Factors Affecting Mobile Services Adoption by Young Consumers in Cameroon. In Proceedings of the World Conference on Information Systems and Technologies; Rocha, Á., Adeli, H., Reis, L.P., Costanzo, S., Eds.; Springer: Berlin/Heidelberg, Germany, 2018; pp. 46-57.

56. Shaikh, A.A.; Glavee-Geo, R.; Karjaluoto, H. How relevant are risk perceptions, effort, and performance expectancy in mobile banking adoption? Int. J. e-Bus. Res. 2018, 14, 39-60. [CrossRef]

57. Tan, E.; Leby Lau, J. Behavioural intention to adopt mobile banking among the millennial generation. Young Consum. 2016, 17, 18-31. [CrossRef]

58. Cimperman, M.; Brencic, M.M.; Trkman, P. Analyzing older users' home telehealth services acceptance behavior-applying an extended utaut model. Int. J. Med. Inform. 2016, 90, 22-31. [CrossRef] [PubMed]

59. Or, C.K.L.; Karsh, B.-T.; Severtson, D.J.; Burke, L.J.; Brown, R.L.; Brennan, P.F. Factors affecting home care patients' acceptance of a web-based interactive self-management technology. J. Am. Med. Assoc. 2011, 18, 51-59. [CrossRef]

60. Chen, A.; Lu, Y.; Wang, B. Enhancing perceived enjoyment in social games through social and gaming factors. Inf. Technol. People 2016, 29, 99-119. [CrossRef] 
61. Kijsanayotin, B.; Pannarunothai, S.; Speedie, S.M. Factors influencing health information technology adoption in Thailand's community health centers: Applying the UTAUT model. Int. J. Med. Inform. 2009, 78, 404-416. [CrossRef]

62. Afshan, S.; Sharif, A. Acceptance of mobile banking framework in Pakistan. Telemat. Inform. 2016, 33, $370-387$. [CrossRef]

63. Alalwan, A.A.; Dwivedi, Y.K.; Rana, N.P. Factors influencing adoption of mobile banking by Jordanian bank customers: Extending UTAUT2 with trust. Int. J. Inf. Manag. 2017, 37, 99-110. [CrossRef]

64. Blaise, R.; Halloran, M.; Muchnick, M. Mobile commerce competitive advantage: A quantitative study of variables that predict m-commerce purchase intentions. J. Internet Commer. 2018, 17, 96-114. [CrossRef]

65. de Kerviler, G.; Demoulin, N.; Zidda, P. Adoption of in-store mobile payment: Are perceived risk and convenience the only drivers? J. Retail. Consum. Serv. 2016, 31, 334-344. [CrossRef]

66. Sharma, S.K.; Govindaluri, S.M.; Al-Muharrami, S.; Tarhini, A. A multi-analytical model for mobile banking adoption: A developing country perspective. Rev. Int. Bus. Strategy 2017, 27, 133-148. [CrossRef]

67. Slade, E.L.; Dwivedi, Y.K.; Piercy, N.C.; Williams, M.D. Modeling consumers' adoption intentions of remote mobile payments in the United Kingdom: Extending UTAUT with innovativeness, risk, and trust. Psychol. Mark. 2015, 32, 860-873. [CrossRef]

68. Baabdullah, M.A. Consumer adoption of Mobile Social Network Games (M-SNGs) in Saudi Arabia: The role of social influence, hedonic motivation and trust. Technol. Soc. 2018, 53, 91-102. [CrossRef]

69. Chaouali, W.; Yahia, B.I.; Souiden, N. The interplay of counter-conformity motivation, social influence, andtrust in customers' intention to adopt Internet banking services: The case of an emerging country. J. Retail. Consum. Serv. 2016, 28, 209-218. [CrossRef]

70. Lu, J.; Liu, C.; Yu, C.-S.; Wang, K. Determinants of accepting wireless mobile data services in China. Inf. Manag. 2008, 45, 52-64. [CrossRef]

71. Bawack, R.E.; Kamdjoug, J.R.K. Adequacy of utaut in clinician adoption of health information systems in developing countries: The case of Cameroon. Int. J. Med. Inform. 2018, 109, 15-22. [CrossRef]

72. Chen, K.; Chan, A.H. Predictors of gerontechnology acceptance by older Hong Kong Chinese. Technovation 2014, 34, 126-135. [CrossRef]

73. Herrero, A.; Del Bosque, I.R. The effect on innovativeness on the adoption of b2b e-commerce: A model based on the theory of planned behavior. Comput. Hum. Behav. 2008, 24, 2830-2847. [CrossRef]

74. San Martín, H.; Herrero, A. Influence on the user's psychological factor on the online purchase intention in rural tourism: Integrating innovativeness to the utaut framework. Tour. Manag. 2012, 33, 341-350. [CrossRef]

75. Escobar-Rodriguez, T.; Carvajal-Trujillo, E. Online purchasing tickets for low cost carriers: An application of the unified theory of acceptance and use of technology (utaut) model. Tour. Manag. 2014, 43, 70-88. [CrossRef]

76. Zarmpou, T.; Saprikis, V.; Markos, A.; Vlachopoulou, M. Modeling users' acceptance of mobile services. Electron. Commer. Res. 2012, 12, 225-248. [CrossRef]

77. Agarwal, R.; Prasad, J. A conceptual and operational definition of personal innovativeness in the domain of information technology. Inf. Syst. Res. 1998, 9, 101-215. [CrossRef]

78. Ramos-de-Luna, I.; Montoro-Rios, F.; Liébana-Cabanillas, F. Determinants of the intention to use NFC technology as a payment system: An acceptance model approach. Inf. Syst. e-Bus. Manag. 2016, 14, $293-314$. [CrossRef]

79. Zarmpou, T.; Saprikis, V.; Vlachopoulou, M. Investigating the influential factors towards mobile services adoption in Greece. In Proceedings of the IADIS International Conference in e-Commerce, Freiburg, Germany, 29-31 July 2010; pp. 69-76.

80. Yi, M.Y.; Fiedler, K.D.; Park, J.S. Understanding the role of individual innovativeness in the acceptance of IT-based innovations: Comparative analyses of models and measures. Decis. Sci. 2006, 37, 393-426. [CrossRef]

81. Yang, S.; Lu, Y.; Gupta, S.; Cao, Y.; Zhang, R. Mobile payment services adoption across time: An empirical study of the effects of behavioral beliefs, social influences, and personal traits. Comput. Hum. Behav. 2012, 28, 129-142. [CrossRef]

82. Tariq, B. Exploring factors influencing the adoption of mobile commerce. J. Internet Bank. Commer. 2007, $12,32-42$. 
83. Kim, D.J.; Ferrin, D.L.; Rao, H.R. A trust-based consumer decision-making model in electronic commerce: The role of trust, perceived risk, and their antecedents. Decis. Support Syst. 2008, 44, 544-564. [CrossRef]

84. Gefen, D.; Karahanna, E.; Straub, D.W. Trust and TAM in online shopping: An integrated model. MIS Q. 2003, 27, 51-90. [CrossRef]

85. Li, X.; Traci, J.-H.; Valacich, J.-S. Why do we trust new technology? A study of initial trust formation with organizational information systems. J. Strateg. Inf. Syst. 2008, 17, 39-71. [CrossRef]

86. Min, Q.; Ji, S.; Qu, G. Mobile commerce user acceptance study in China: A revised UTAUT model. Tsinghua Sci. Technol. 2008, 13, 257-264. [CrossRef]

87. Akman, I.; Mishra, A. Factors influencing consumer intention in social commerce adoption. Inf. Technol. People 2017, 30, 356-370. [CrossRef]

88. Meharia, P. Assurance on the reliability of mobile payment system and its effects on its'use: An empirical examination. Account. Manag. Inf. Syst. 2012, 11, 97-111.

89. Ming-Hsien, Y.; Chandlrees, N.; Binshan, L.; Sc Hung-Yi, C. The effect of perceived ethical performance of shopping websites on consumer trust. J. Comput. Inf. Syst. 2009, 50, 15-24.

90. Wang, Y.; Emurian, H.-H. An overview of online trust: Concepts, elements, and implications. Comput. Human Behav. 2005, 21, 105-125. [CrossRef]

91. Wei, T.; Marthandan, G.; Chong, A.; Ooi, K.; Arumugam, S. What drives Malaysian mcommerce adoption? An empirical analysis. Ind. Manag. Data Syst. 2009, 109, 370-388.

92. Shin, D.-H. Towards an understanding of the consumer acceptance of mobile wallet. Comput. Hum. Behav. 2009, 25, 1343-1354. [CrossRef]

93. Mathwick, C.; Malhotra, N.; Rigdon, E. Experiential value: Conceptualization, measurement and application in the catalog and internet shopping environment. J. Retail. 2001, 78, 51-60. [CrossRef]

94. Morgan, R.M. Relationship Marketing and Marketing Strategy: The Evolution of Relationship Marketing within the Organization. In Handbook of Relationship, Marketing; Sheth, J., Parvatiyar, A., Eds.; Sage: Thousand Oaks, CA, USA, 2000; pp. 481-505.

95. Kannan, P.K.; Chang, A.; Whinston, A.B. Wireless commerce: Marketing issues and possibilities. In Proceedings of the 34th Hawaii International Conference on System Sciences, Maui, HI, USA, 3-6 January 2001; pp. 1-6.

96. Pavlou, P. Consumer acceptance of electronic commerce: Integrating trust and risk with the technology acceptance model. Int. J. Electron. Commer. 2003, 7, 101-134.

97. Yu, Y.; Buahom, K. Exploring factors influencing consumer adoption on mobile commerce services. Bus. Rev. 2013, 21, 258-265.

98. Nysveen, H.; Pedersen, P.; Thorbjornsen, H.; Berthon, P. Mobilizing the brand: The effects of mobile services on brand relationships and main channel use. J. Serv. Res. 2005, 7, 257-276. [CrossRef]

99. Petina, A.; Amialchuk, A.; Taylor, D. Exploring effects of online shopping experiences on browser satisfaction and e-tail performance. Int. J. Retail Distrib. Manag. 2011, 39, 742-758. [CrossRef]

100. Doyle, S. Software review: Using short message services as a marketing tool. J. Database Mark. 2001, 8, $273-277$. [CrossRef]

101. Watson, R.; Pitt, F.; Berthon, P.; Zinkhan, G. U-Commerce: Expanding the universe of marketing. J. Acad. Mark. Sci. 2002, 30, 333-347. [CrossRef]

102. Jang, H.; Ko, I.; Kim, J. The effect of group-buy social commerce and coupon on satisfaction and continuance intention. In Proceedings of the 46th Hawaii International Conference on System Sciences, Wailea, Maui, HI, USA, 7-10 January; pp. 2938-2948.

103. Idoko, C.E.; Ukenna, I.S.; Obeta, E.C. Determinants of shopping mall patronage frequency in a developing economy: Evidence from Nigerian mall shoppers. J. Retail. Consum. Serv. 2019, 48, 186-201. [CrossRef]

104. Saprikis, V. A longitudinal investigation on Greek university students' perceptions towards online shopping. J. Electron. Commer. Organ. 2013, 11, 43-62. [CrossRef]

105. Saprikis, V.; Antoniadis, I. An Empirical Investigation on University Students' Perceptions toward Contactless Card Adption and Use for Financial Transactions. In Proceedings of the 33nd IBIMA Conference, Granada, Spain, 10-11 April 2019; pp. 1425-1437.

106. Shead, W.; Derevensky, J.; Fong, T.; Gupta, R. Characteristics of internet gamblers among a sample of students at a large, public university in Southwestern United States. J. Coll. Stud. Dev. 2012, 53, 133-148. [CrossRef]

107. Govender, I.; Sihlali, W. A study of mobile banking adoption among university students using extended TAM. Mediterr. J. Soc. Sci. 2014, 5, 451-459. [CrossRef] 
108. Yáñez-Luna, J.C.; Arias-Oliva, M. M-learning: Technological acceptance of mobile devices in online learning. Tecnol. Cienc. Y Educ. 2018, 10,13-34.

109. Palos-Sanchez, P.; Saura, J.R.; Martin-Velicia, F. A study of the effects of Programmatic Advertising on users' Concerns about Privacy overtime. J. Bus. Res. 2019, 96, 61-72. [CrossRef]

110. HAS. Hellenic Statistical Authority_Demographic Characteristics. 2011. Available online: https://www. statistics.gr/en/statistics/-/publication/SAM03/- (accessed on 16 September 2020).

111. Hair, J.; Black, W.; Babin, B.; Anderson, R. Multivariate Data Analysis, 3rd ed.; Pearson/Prentice Hall: Upper Saddle River, NJ, USA, 2014.

112. Bagozzi, P.; Yi, Y. On the evaluation of structural equation models. J. Acad. Mark. Sci. 1998, 16, 74-94. [CrossRef]

113. Fornell, C.; Larcker, D.F. Structural equation models with unobservable variables and measurement error: Algebra and statistics. J. Mark. Res. 1981, 18, 382-388. [CrossRef]

114. Podsakoff, P.M.; MacKenzie, S.B.; Lee, J.Y.; Podsakoff, N.P. Common method biases in behavioral research: A critical review of the literature and recommended remedies. J. Appl. Psychol. 2003, 88, 879-903. [CrossRef] [PubMed]

115. Bentler, M. Comparative fit indexes in structural models. Psychol. Bull. 1990, 107, 238-246. [CrossRef] [PubMed]

116. Hu, L.T.; Bentler, P.M. Cutoff criteria for fit indexes in covariance structure analysis: Conventional criteria versus new alternatives. Struct. Equ. Modeling 1999, 6, 1-55. [CrossRef]

117. Muthén, L.K.; Muthén, B.O. Mplus for Windows 7.31; Muthén \& Muthén: Los Angeles, CA, USA, 2015.

118. Kline, R.B. Principles and Practice of Structural Equation Modeling, 2nd ed.; The Guilford Press: New York, NY, USA, 2005.

119. Fogg, B.J. Persuasive Technology: Using Computers to Change What We Think and Do; Kaufmann Publishers: San Francisco, CA, USA, 2003.

120. Ashforth, B.E. Role Transitions in Organizational Life: An Identity-Based Perspective; Lawrence Erlbaum Associates: Mahwah, NJ, USA, 2001.

121. Saprikis, V.; Markos, A.; Zarmpou, T.; Vlachopoulou, M. Mobile shopping consumers' behavior: An exploratory study and review. J. Theor. Appl. Electron. Commer. Res. 2018, 13, 53-71. [CrossRef]

122. Guo, Y.; Barnes, S. Virtual item purchase behavior in virtual worlds: An exploratory investigation. Electron. Commer. Res. 2009, 9,77-96. [CrossRef]

123. Chiou, J.S.; Shen, C.C. The Antecedents of online financial service adoption: The impact of physical banking services on internet banking acceptance. Behav. Inf. Technol. 2012, 31, 859-871. [CrossRef]

Publisher's Note: MDPI stays neutral with regard to jurisdictional claims in published maps and institutional affiliations.

(C) 2020 by the authors. Licensee MDPI, Basel, Switzerland. This article is an open access article distributed under the terms and conditions of the Creative Commons Attribution (CC BY) license (http://creativecommons.org/licenses/by/4.0/). 